\title{
Holistic Environmental Approaches and Aichi Biodiversity Targets: accomplishments and perspectives for marine ecosystems
}

Elliot Dreujou Corresp., 1, 2 Charlotte Carrier-Belleau ${ }^{2}$, Jesica Goldsmit ${ }^{2,3}$, Dario Fiorentino ${ }^{4,5}$, Radhouane Hamadou $^{6}$, Jose H Muelbert ${ }^{7,8}$, Jasmin A Godbold ${ }^{9}$, Rémi M Daigle ${ }^{2}$, David Beauchesne ${ }^{1}$

${ }^{1}$ Institut des Sciences de la Mer, University of Québec at Rimouski, Rimouski, Québec, Canada

2 Department of Biology, Laval University, Québec, Québec, Canada

3 Maurice Lamontagne Institute, Fisheries and Oceans Canada, Mont-Joli, Québec, Canada

${ }^{4}$ Helmholtz Institute for Functional Marine Biodiversity, University of Oldenburg, Oldenburg, Germany

5 Alfred Wagner Institute, Helmholtz Centre for Polar and Marine Research, Bremerhaven, Germany

${ }^{6}$ Department of Biological and Environmental Sciences, College of Arts and Sciences, Qatar University, Doha, Qatar

7 Instituto de Oceanografia, Universidade Federal do Rio Grande, Rio Grande, Brazil

8 Institute for Marine and Antarctic Sciences, University of Tasmania, Hobart, Australia

${ }^{9}$ School of Ocean and Earth Science, University of Southampton, National Oceanography Center, Southampton, United Kingdom

Corresponding Author: Elliot Dreujou

Email address: elliot.dreujou@icloud.com

In order to help safeguard biodiversity from global changes, the Conference of the Parties developed a Strategic Plan for Biodiversity for the period 2011-2020 that included a list of twenty specific objectives known as the Aichi Biodiversity Targets. With the end of that timeframe in sight, and despite major advancements in biodiversity conservation, evidence suggests that the majority of the Targets are unlikely to be met. This paper is part of a series of perspective pieces from the $4^{\text {th }}$ World Conference on Marine Biodiversity (May 2018, Montréal, Canada) to identify next steps towards successful biodiversity conservation in marine environments. We specifically reviewed holistic environmental assessment studies (HEA) and their contribution to reaching the Targets. Our analysis was based on multiple environmental approaches which can be considered as holistic, and we discuss how HEA can contribute to the Aichi Biodiversity Targets in the near future. We found that only a few HEA articles considered a specific Biodiversity Target in their research, and that Target 11, which focuses on marine protected areas, was the most commonly cited. We propose five research priorities to enhance HEA for marine biodiversity conservation beyond 2020: (i) expand the use of holistic approaches in environmental assessments, (ii) standardize HEA vocabulary, (iii) enhance data collection, sharing and management, (iv) consider ecosystem spatio-temporal variability and (v) integrate ecosystem services in HEA. The consideration of these priorities will promote the 
value of HEA and will benefit the Strategic Plan for Biodiversity. 


\section{Holistic Environmental Approaches and Aichi Biodiversity \\ 2 Targets: accomplishments and perspectives for marine \\ 3 ecosystems}

5 Elliot Dreujou ${ }^{1,2}{ }^{*}$, Charlotte Carrier-Belleau ${ }^{2}$, Jesica Goldsmit ${ }^{2,3}$, Dario Fiorentino ${ }^{4,5}$, Radhouane Ben-

6 Hamadou ${ }^{6}$, Jose H. Muelbert ${ }^{7,8}$, Jasmin A. Godbold ${ }^{9}$, Rémi M. Daigle ${ }^{2}$ and David Beauchesne ${ }^{1,2}$

7

$8{ }^{1}$ Institut des Sciences de la Mer, University of Québec at Rimouski, Rimouski, QC, Canada

$9 \quad 2$ Department of Biology, Laval University, Québec, QC, Canada

$10{ }^{3}$ Maurice Lamontagne Institute, Fisheries and Oceans Canada, Mont-Joli, QC, Canada.

$11{ }^{4}$ Helmholtz Institute for Functional Marine Biodiversity, University of Oldenburg, Oldenburg, Germany

$12{ }^{5}$ Alfred Wegener Institute, Helmholtz Centre for Polar and Marine Research, Bremerhaven, Germany

$13{ }^{6}$ Department of Biological and Environmental Sciences, College of Arts and Sciences, Qatar University, 14 Doha, Qatar

$15{ }^{7}$ Instituto de Oceanografia, Universidade Federal do Rio Grande, Rio Grande, Brazil

$16{ }^{8}$ Institute for Marine and Antarctic Sciences, University of Tasmania, Hobart, Australia

$17{ }^{9}$ School of Ocean and Earth Science, University of Southampton, National Oceanography Centre,

18 Southampton, United Kingdom

19

20 Corresponding Author:

21 Elliot Dreujou *

22 300, Allée des Ursulines, Rimouski, Québec, G5L 3A1, Canada

23

24 Email address: elliot.dreujou@uqar.ca 


\section{Abstract}

26 In order to help safeguard biodiversity from global changes, the Convention on Biological

27 Diversity developed a Strategic Plan for Biodiversity for the period 2011-2020 that included a

28 list of twenty specific objectives known as the Aichi Biodiversity Targets. With the end of that

29 timeframe in sight, and despite major advancements in biodiversity conservation, evidence

30 suggests that the majority of the Targets are unlikely to be met. This paper is part of a series of

31 perspective pieces from the 4th World Conference on Marine Biodiversity (May 2018, Montréal,

32 Canada) to identify next steps towards successful biodiversity conservation in marine

33 environments. The aim of our work was to discuss the relevance of Holistic Environmental

34 Assessment (HEA) in regards to the Aichi Biodiversity Targets. We reviewed multiple

35 environmental approaches which could be considered as holistic, and we discuss how HEAs can

36 contribute to the Aichi Biodiversity Targets in the near future. We found that only a few HEA

37 articles considered a specific Target in their research, and that Target 11, which focuses on

38 marine protected areas, was the most commonly cited. We propose five research priorities to

39 enhance HEAs for marine biodiversity conservation beyond 2020: (i) expand the use of holistic

40 approaches in environmental assessments, (ii) standardize HEA vocabulary, (iii) enhance data

41 collection, sharing, and management, (iv) consider ecosystem spatio-temporal variability, and (v)

42 integrate ecosystem services in HEAs. The consideration of these priorities will promote the

43 value of HEAs and will benefit the Strategic Plan for Biodiversity. 


\section{1. Introduction}

45 In 2010, the 10th Conference of the Parties revised and updated the Strategic Plan for 46 Biodiversity from the Convention on Biological Diversity (CBD), which included the Aichi

47 Biodiversity Targets for 2011-2020 (Secretariat of the CBD, 2010). The mission of the Strategic

48 Plan for Biodiversity is to "take effective and urgent action to halt the loss of biodiversity in 49 order to ensure that by 2020 ecosystems are resilient and continue to provide essential services 50 [...]" (Secretariat of the CBD, 2010). According to United Nations (1992), biodiversity refers to 51 "the variability among living organisms from all sources including, inter alia, terrestrial, marine 52 and other aquatic ecosystems and the ecological complexes of which they are part; this includes 53 diversity within species, between species and of ecosystems". Yet, despite recent small- and

54 large-scale conservation and management efforts, including the development of global protected 55 area networks (Butchart et al., 2015), evidence suggests that most of the Targets are unlikely to 56 be met (Secretariat of the CBD, 2014) as species declines and extinctions continue to occur 57 (Tittensor et al., 2014).

58 With the end of the Strategic Plan for Biodiversity in sight, the time is ripe to reflect on 59 accomplishments thus far and to identify the next steps towards successful biodiversity 60 conservation in marine ecosystems. These steps will be critical to meet the Sustainable Development Goal 14, which aims for the conservation and sustainable use of the oceans, seas, and marine resources by 2030 (SDG, 2019). These topics were tackled during the 4th World Conference on Marine Biodiversity held in Montréal, Canada, in May 2018, which gathered marine biodiversity experts from around the world. A mentoring program was devised to bring senior and early-career scientists together to address this challenge, which resulted in a series of perspective pieces, including this article. Holistic Environmental Approaches (HEA) were identified as crucial to marine biodiversity conservation by program participants.

In the present study, we define HEAs as environmental planning, assessment, management, or monitoring strategies that use a whole-system approach to explicitly consider and prioritize ecosystem complexity. Holism is dependent on components, connections, and boundaries of the considered ecosystems. While HEAs focus on natural ecosystems, they may include additional 72 dimensions (e.g. social, cultural and economic) relevant to the ecosystem under consideration.

73 There is little doubt that the complexity of ecosystems must be considered for successful marine 
74 biodiversity conservation, yet the contribution of HEAs to marine biodiversity conservation in 75 general and to the Aichi Biodiversity Targets in particular is unclear. In this perspective paper, 76 we review the prevalence of HEAs in the peer-reviewed marine biodiversity literature and 77 discuss their relevance to reaching the Aichi Biodiversity Targets, with a focus on the ecological 78 dimension of HEAs. We then propose research priorities to enhance HEAs for marine 79 biodiversity conservation beyond 2020 .

80

81

82

83

84 85 86

\section{Literature review}

\subsection{Methodology}

To better understand the uses of HEAs and their relevance for the Strategic Plan for Biodiversity, we searched the peer-reviewed scientific literature between January 1990 and July 2019 (inclusive). We used the ISI Web of Knowledge database and we queried the title, keywords, and abstract of original research articles. Non-peer reviewed literature, such as technical reports or assessment tools, were not included in this review as we considered that it could produce an important bias by the selection of studies related only to a specific region or for a specific use.

We constrained our search to environmental studies by using the search terms ecology, ecosystem, environment, habitat, species and biodiversity as an initial filtering criteria (Table 1).

We then further selected articles that focused on marine environments only.

A list of HEAs was established by gathering expert opinion from researchers in the field of marine ecology and environmental conservation. This process led to the inclusion of nine HEAs: adaptive management (Stankey, Clark \& Bormann, 2005), cumulative impact assessment (Jones, 2016), ecosystem-based management (Link, 2002; Pikitch et al., 2004; Levin et al., 2009), integrated management (Cicin-Sain \& Belfiore, 2005), marine spatial planning (Santos et al., 2019), social-ecological networks (Baggio \& Hills, 2018), strategic environmental assessment (Gunn \& Noble, 2009; 2011), sustainable resource management (Bringezu \& Bleischwitz, 2017), and systematic conservation planning (Margules \& Pressey, 2000). We used all HEA collectively as a search query on the initial corpus, then each HEA was queried individually to determine their prevalence in the literature (Table 1). Finally, we used the search term Aichi in order to determine if and how Aichi Biodiversity Targets were considered in HEA studies. 
2.2. Prevalence of HEAs in the marine biodiversity literature

106 Our review identified 1,648 research articles related to biodiversity studies that used any of the

107

108

109

110

111

112

113

114

115

116

117

118

119

120

121

122

123

124

125

126

127

128

129

130

131

132

133 identified HEAs, with 505 articles targeting marine environments. We found that the term ecosystem-based management was the most represented HEA (40.2\%), followed by marine spatial planning (31.5\%) (Fig. 1). Other HEAs were less represented in the scientific literature, with systematic conservation planning, adaptive management and integrative management referred to in $16.4 \%, 13.7 \%$ and $8.5 \%$ of the identified literature, respectively (Fig. 1). Overall, few studies have considered multiple HEAs simultaneously, with 39 articles having the highest overlap between ecosystem-based management and marine spatial planning. When analyzing the keywords that were used in the reviewed articles, the most prevalent HEAs were "ecosystembased management" and "marine spatial planning". Another common keyword was "marine protected areas", highlighting the relatively common use of this tool in marine conservation programs.

The results show that HEAs were rarely discussed before 2006, and the number of HEA articles peaked in 2013, 2014 and 2018 (Fig. 1). Overall, there was a steady increase in the number of HEA articles since 2000. This is particularly true for marine HEAs where the number of studies increased notably two years after the development of the Aichi Biodiversity Targets in 2010 (Fig. 1). This increase after 2012 appears to be largely driven by a rise in the number of ecosystem-based management and marine spatial planning studies, which is likely a reflection of the time required for Aichi-related frameworks to be implemented in research supporting the management of socio-ecological systems (e.g. White et al., 2010).

Of all the studies on HEAs, only 12 specifically used the term Aichi Targets, representing $2.4 \%$ of the papers originally identified (Table 2). This is a low proportion of HEAs contributing to the Strategic Plan for Biodiversity, even if we acknowledge that a study does not need to focus on a specific Target to allow a contribution. In addition, nine studies explicitly considered Targets in their research objectives (Table 2). The most frequently mentioned Aichi Biodiversity Target was Target 11, which aims for the conservation of $10 \%$ of coastal and marine areas by 2020 (Secretariat of the CBD, 2010). This Target is one of the few that specifically identifies quantitative thresholds for protected areas (Harrop, 2011), which supports the development of 
134 well specified and measurable objectives and tools such as simple, measurable, accurate, 135 realistic, time-bound indices (SMART). HEAs could use SMART objectives, although there are 136 few examples of their use in this context (Ehler, 2017). Specifying SMART objectives can be a 137 difficult task, but their measurable component can highlight successful accomplishment of 138 expected thresholds (Ehler, 2017; and references therein). Many studies selected in our literature 139 review evaluated progress and developments of marine protected areas (e.g. Amengual \& 140 Alvarez-Berastegui, 2018; Jantke et al., 2018; Rees et al., 2018). Target 11 has also been used to 141 evaluate case studies (Diz et al., 2018), and to identify the sustainable use of specific marine 142 protected areas as part of workshops and wider consultations (Johnson et al., 2014; Sarker et al., 143 2019). Other selected studies considered either a specific Aichi Biodiversity Target, such as 144 Target 12 in Davidson \& Dulvy (2017) or Target 19 in Lagabrielle et al. (2017), or multiple 145 Targets, such as Targets 1, 3, 6, and 17 in Cisneros-Montemayor, Singh \& Cheung (2018) or 146 Targets 6, 10, 11, and 12 in Davies et al. (2017) (Table 2). Five articles did not use Aichi Targets 147 in their specific objectives, but were included to set the wider context of the article (e.g.

148 Lagabrielle et al., 2014; Yamakita et al., 2015; Davidson \& Dulvy, 2017; Davies et al., 2017; 149 Novaczek et al., 2017) (Table 2).

150

2.3. Linking HEAs and the Strategic Plan for Biodiversity

152 Strategic Goals have been identified by the CBD as the steps necessary to safeguard biodiversity 153 by 2020 (Fig. 2A). These Goals include mainstreaming biodiversity across government and 154 society (Goal A), reducing direct pressures on biodiversity (Goal B), improving the status of 155 biodiversity (Goal C), enhancing benefits from biodiversity and ecosystem services (Goal D) and 156 enhancing implementation of the established measures (Goal E) (Secretariat of the CBD, 2010). 157 Aichi Biodiversity Targets have been set within each Goal, with specific objectives or 158 quantitative thresholds to reach (Fig. 2B). Our literature review gathered a large number of HEA 159 studies where a few referred to Targets in their objectives and methods (Table 1). Collectively, 160 we found that these studies have focussed on eight Targets, with five being specified as 161 objectives of the study (Table 2, Fig. 2C). This provides examples of how HEAs can contribute 162 to the Strategic Plan for Biodiversity while also providing feedback to reach specific Targets 
163 (Fig. 2B-C). We will discuss some examples of these relationships in more detail in the section 164 below.

165 Modern sustainable development objectives include minimizing cross-scale human impacts on 166 biodiversity; concurrently, management plans are increasingly integrating social and economic 167 dimensions (IPCC, 2014; Steffen et al., 2015). Thus, by also considering these same dimensions, 168 HEAs explicitly include stakeholder involvement, public consultations or social initiatives, 169 which is in accordance to Target 1 . When made available to the public, the use of a whole170 system approach within HEAs, in order to embrace ecosystem complexity, can raise awareness 171 about biodiversity (Palerm, 2000; Portman, 2009; Jarvis et al., 2015). Implementation of 172 conservation actions are usually complicated due to the variety of people concerned and the 173 commercial interests of the different stakeholders (Margules \& Pressey, 2000), but also because 174 marine settings are particularly challenging, as stakeholders and objectives tend to be less well175 defined (Cisneros-Montemayor, Singh \& Cheung, 2018). HEAs that take into account the natural 176 variability of ecosystems, such as adaptive management or ecosystem-based management, 177 should include social and political involvement (Stankey, Clark \& Bormann, 2005).

178 HEAs should also favor whole-system approaches to prioritize management actions based on 179 ecosystem services, which relates to human use of environments (Carpenter et al., 2009; Chan \& 180 Ruckelshaus, 2010; Kareiva et al., 2011; Queiroz et al., 2015). Cumulative impact assessments, 181 for example, focus on drivers of change and mechanistic pathways of impact in order to 182 prioritize management efforts and take into account ecosystem services and thus, socio-economic 183 dimensions (Brown et al. 2013, Cook et al. 2014; Cisneros-Montemayor, Singh \& Cheung, 184 2018). These approaches can be linked with Target 3's objectives to decrease negative effects on 185 biodiversity and encourage conservation and sustainable use of biodiversity.

186 Target 6 states that fish and invertebrate stocks and aquatic plants are managed and harvested 187 sustainably, legally, and applying ecosystem-based approaches, so that overfishing is avoided, 188 recovery plans and measures are in place for all depleted species, fisheries have no significant 189 adverse impacts on threatened species and vulnerable ecosystems, and the impacts of fisheries on 190 stocks, species and ecosystems are within safe ecological limits. HEAs, such as ecosystem-based 191 management, resource management and adaptive management (along with all the processes 192 linked to theses approaches) will provide the tools to a better understanding of the species, 
193 stocks, and habitats as well as their interactions in ecosystems (Arkema, Abramson \& Dewsbury, 194 2006). These tools may be applied to a variety of concrete case studies, ranging from the 195 conservation of marine mammals to coral reef protection (Maggs, Mann \& Cowley, 2013;

196 Authier et al., 2017), but also to discuss the adequacy and performance of management strategies 197 (Johnson et al., 2014; Cisneros-Montemayor, Singh \& Cheung, 2018).

198 With the aim of improving the status of biodiversity, governments and companies are required to 199 enforce measures to safeguard ecosystems and all components therein (Secretariat of the CBD, 200 2010). In this context, HEAs can provide tools to accurately predict ecosystem consequences for 201 systems threatened by multiple drivers of change (Nilsson \& Dalkman, 2001). For example, for 202 Target 11 and the conservation of marine and coastal areas, HEAs have a direct contribution by 203 being related and concerned with management, planning, and conservation. HEAs can also be 204 helpful in the identification and assessment of threats by being able to manage the multiple and 205 simultaneous drivers of change and stress.

206 The implementation of plans and strategies through participatory actions, such as proposed in 207 Target 17, requires the production of concrete tools to manage environmental use. The correct 208 implementation of HEAs can support the development of ecological indices to integrate different 209 ecosystem components in a coherent methodology, since the need for operational tools within 210 management plans has been highlighted (Arkema, Abramson \& Dewsbury, 2006; Cisneros211 Montemayor, Singh \& Cheung, 2018). In fact, these types of assessments are better undertaken 212 when they are done strategically and expressed in a measurable way, e.g. using SMART 213 objectives (Jones 2016).

\section{3. Research priorities}

217 HEAs should integrate every component of the studied ecosystems. However, logistical, 218 technical and monetary considerations may limit the feasibility of such a goal. Nonetheless, 219 'partial' HEAs are often more valuable than specific environmental assessments (Jones, 2016). 220 The complexity and breadth of knowledge needed for 'full' HEAs makes them exceedingly 221 difficult to implement, which may likely explain the relatively small number of studies found 222 applying holistic approaches to ecosystem management (Table 1). In order to achieve the goals 
223 set by the Strategic Plan for Biodiversity, there is a need to develop management actions beyond 2242020 (Secretariat of the CBD, 2014). Discussions to identify the strategic direction for a post2252020 global biodiversity framework are taking place (e.g. IX Trondheim Conference on 226 Biodiversity), and the need for holistic management actions for a sustainable environment has 227 been highlighted.

228 With this in mind, research priorities for the application of HEAs in marine environments were 229 identified during the 4th World Conference on Marine Biodiversity as part of a mentoring 230 program. Participants worked individually to identify research priorities before the conference, in 231 order to provide a comprehensive list for the conference. This list was then used by participants 232 to collectively curate a list of the top research priorities. This selection was discussed with 233 conference attendees through panel discussions during the conference and comments were used 234 to refine priorities post-conference. This process yielded a list of five research priorities (Fig. 235 2D). The steps to undertake, in order to develop and promote the use of holistic approaches for 236 marine biodiversity conservation, are discussed below.

237

3.1. Priority I: Expand the use of holistic approaches in environmental assessments Marine biodiversity spans different levels of biological organization (Hagen et al., 2012). The various biological components of a given ecosystem are continuously interacting with their environment within complex ecological networks. However, many environmental assessments

242 focus on a single species or a single component of the ecosystem, overlooking important abiotic

243 and biotic interactions that significantly affect the way organisms interact with their environment 244 and mediate ecosystem functioning (Crain, Kroeker \& Halpern, 2008; Bulleri, 2009; van der Plas 245 2019). Therefore, accurately assessing ecological functioning of marine ecosystems and their 246 environmental, social and economic sustainability requires a holistic approach (Burton et al., 247 2014; Ma et al., 2017).

248 Characterization of marine biodiversity and ecosystem functioning can be achieved through 249 theoretical, numerical, experimental or monitoring approaches (Costello et al., 2017; Eriksen et 250 al., 2018). Emerging environmental DNA techniques consisting of DNA metabarcoding and 251 metagenomics (e.g. Thomsen \& Willerslev, 2015) offer potentially powerful new tools to 252 monitor marine biodiversity and detect new species introductions. This allows reduced 
253 investment in traditional taxonomic techniques and biodiversity sampling and provides new 254 opportunities to assess challenging and remote locations (Brown et al., 2016; Lacoursière255 Roussel et al., 2018). Moreover, scientific research vessels now deploy vast arrays of equipment 256 and gears simultaneously to answer increasingly complex research questions about whole 257 ecosystems rather than as individual components (e.g. Pesant et al., 2015). These new emerging 258 methodologies and technologies can complement current holistic approaches such as cumulative effects assessments (Halpern et al. 2008; 2015) or systematic conservation planning (Margules \&

260 261

262 263

264 265 266

267

268

269

270

271

272

273

274

275

276

277

278

279

280

281

282 Pressey 2000; Ball, Possingham \& Watts, 2009; Daigle et al. 2019). Managers increasingly recognize the need to shift towards holistic approaches to generate informed actions more inclusive of the relationships between ecosystem components than those obtained by traditional single-species efforts (e.g. Manley et al., 2004; Beever, 2006).

The use of HEAs is relevant to all Targets within Goals B and C. In particular, expanding the use of holistic approaches could benefit Target 11's conservation objectives and perspectives by considering the complexity of the ecosystems (Rees et al., 2018).

\subsection{Priority II: Standardize HEAs vocabulary}

What is a "driver of change", and when does it become a "stressor"? What constitutes an "impact"? The need to adopt a common vocabulary is especially important for multidisciplinary approaches in which communication between actors with a variety of backgrounds is often impeded by semantics (Holt et al. 2011). For example, the scientific community frequently uses the expression "cumulative effects assessment", but the underlying principles are often poorly understood, which may impact the interpretation of these assessments. Along with the definition of a concept, the origins behind the terminology must be explored and the terms standardized prior to their application across disciplines (Judd, Backhaus \& Goodsir, 2015).

Analytical frameworks such as DPSIR (Drivers, Pressures, State, Impact, Response) models are useful for HEAs if all of the included elements are well defined and consistent (Kelble et al., 2013). However, Lewison et al. (2016) and Gari et al. (2014) found that despite the widespread application of individual terms across disciplines and projects, there is still no consensus on the definitions of "pressure" and "impact". These different interpretations decrease the understanding and operationalization of HEAs across scientists, stakeholders, and decision 
283 makers (Gari et al., 2014). The strengths of DPSIR frameworks, such as the capacity to describe

284 linkages between human activity and environmental issues, encourage transdisciplinary research

285 and will benefit many disciplines once its components are clarified (Kelble et al., 2013; Lewison 286 et al., 2016).

287 While vocabulary standardization does not contribute directly to a specific Aichi Biodiversity 288 Target, it will promote the applicability of HEAs by facilitating communication between actors, 289 which could ultimately be advantageous to all Strategic Goals and Aichi Biodiversity Targets.

290

291

3.3. Priority III: Enhance data collection, sharing, and management practices

292 The application of HEAs is highly dependent on efficient data collection, sharing, and 293 management. However, constructing large datasets for holistic approaches is a challenging 294 endeavour whose complexity is compounded by decentralized digital infrastructure and 295 heterogenous practices (Wilkinson et al., 2016). To this end, we have identified three steps to 296 promote data collection, sharing, and management efficiency for use in HEAs.

297 Firstly, it is imperative to develop proper mechanisms to incentivize researchers to share their 298 data publicly. In order to accelerate scientific discoveries and optimize research investments, 299 many scientific journals and governmental agencies have initiated strong policies to promote public data archiving (Tenopir et al., 2011; Poisot, Mounce \& Gravel, 2013; Roche et al., 2015). Regardless, many researchers remain reluctant to share their data publicly (Tenopir et al., 2011; Hampton et al., 2013; Roche et al., 2014), highlighting the lack of widespread mechanisms to give proper scientific value to data products (Wilkinson et al., 2016).

304 Secondly, our digital infrastructure should be improved so that data needed for HEAs are easily 305 and openly accessible to all practitioners, scientists, and the public. We recommend adhering and promoting the FAIR Data Principles, which states that data must be Findable, Accessible, Interoperable, and Reusable (Wilkinson et al., 2016; Tanhua et al., 2019). This emerges as a crucial step to foster proper data management practices and to provide quality data and knowledge relevant to HEAs. Open-access data resources such as the Ocean Biodiversity Information System (OBIS, 2019) and the Global Biodiversity Information Facility (GBIF, 
311 2019) exemplify excellent and easily accessible sources that can be used by researchers to share 312 their data.

313 Finally, we should strive for global standardization of ocean practices. Defining clear standards

314 and protocols will favour compatibility and pave the way towards efficient HEAs by facilitating

315 the aggregation of local and regional datasets into large, holistic datasets. Initiatives that seek

316 such standardization in practices, such as the Essential Ocean Variables from the Global Ocean

317 Observing System (GOOS, 2019) and the Ocean Best Practices repository (OBP, 2019) from the

318 International Oceanographic Data and Information Exchange, should thus be highly promoted.

319 Addressing these three steps will enhance data and protocol management, along with knowledge 320 transfer and interoperability, which are necessary for efficient and robust HEAs. This will, in 321 turn, facilitate education and outreach, management and conservation actions, evaluation of 322 ecosystem services, data sharing and capacity building, which are the cornerstones of the 323 Strategic Plan for Biodiversity.

324

3.4. Priority IV: Consider ecosystem spatio-temporal variability

326

327

328

329

330

331

332

333

334

335

336

337

338

339

Ecosystem studies widely recognize the importance of spatial and temporal scales, as they influence ecosystem components (e.g. fauna, flora), and characterize ecological processes (Legendre, 1993, Hagen et al., 2012; Pittman, 2017). Organism-environment interactions occur across a variety of spatio-temporal scales (e.g. Legendre \& Gauthier, 2014; Kraan et al., 2015; Yeager et al. 2017; Ryo et al. 2019), but only few HEA studies have acknowledged the need to consider these variations, for example by comparing different seasons or locations (e.g. de la Vega et al., 2018a; 2018b). Despite available methodologies to investigate spatio-temporal patterns within ecosystems (e.g. Baselga, 2010; Legendre \& Gauthier, 2014), we are unaware of environmental assessments that investigated multiple spatio-temporal structures concurrently in marine environments.

In addition to the organism-environment interactions, spatio-temporal structures can also affect human activities in an economic context. This can be seen with fisheries management, where activities occur across multiple spatio-temporal scales by involving single boat and fleet activities and managed to exploit targeted resources most efficiently (Hilborn, 2007; Watson et 
340 al., 2018). For example, tuna fishermen may be three times more profitable if fishing on strong

341 oceanographic fronts (i.e. Lagrangian coherent structures; Watson et al., 2018). This implies that

342 the effects of a physical feature of the water column can trickle through the local food web,

343 ultimately affecting fisheries profitability at the spatial and temporal scale of the physical feature.

344 Human activities can interact directly and indirectly with a variety of natural drivers, such as

345 shear stress, storms or currents, at different spatio-temporal scales (van Denderen et al., 2015;

346 Watson et al., 2018). These interactions may trigger biodiversity responses that consequently

347 appear at different levels of organization, influencing both faunal composition and functions that

348 ultimately impact ecosystem functions and services. In order to develop successful conservation

349 actions, HEAs require further understanding of the spatio-temporal structure of ecosystems and

350 the scales of variability of related ecological patterns and processes, in order to adapt to their 351 variability.

352 With respect to the Aichi Biodiversity Targets, assessing scales of spatio-temporal variability

353 through HEAs will assist in reducing the impacts of human activities on ecosystems and species

354 (Goal B), and to enhance management strategies to improve the status of critical areas (Goal C).

355

356

357 358

359

360

361

362

363

364

365

366

367

368

\subsection{Priority V: Integrate ecosystem services}

The concept of "ecosystem services" has initiated the creation of a set of principles to be used by researchers and managers to support ecosystem conservation initiatives (de Groot, Wilson \& Boumans, 2002; Beaumont et al., 2007). Ecosystem services are the benefits that humans gain from the natural environment (MEA, 2005). They include provisioning (e.g. production of food or raw materials), regulating (e.g. water purification, carbon sequestration), supporting (e.g. soil production, primary production) and cultural services (e.g. aesthetic, recreation) (Beaumont et al., 2007; Fisher, Turner \& Morling, 2009; Atkins et al., 2011; Balmford et al. 2011). Such services may be used to find compromises between providing a hospitable environment for human populations, maintaining ecosystem patterns, and processes within a sustainable range of variation (Beaumont et al., 2007; Cardinale et al., 2012; Norris, 2012). Because ecosystem services consider multiple aspects of the ecosystems within integrative frameworks, they will be highly relevant in HEAs.

Peer) reviewing PDF | (2019:02:34984:2:0:NEW 27 Oct 2019) 
369 Management and consideration of each ecosystem service category is often not equivalent within

370 policy, resulting in a possible mismatch with environmental assessment in terms of spatio-

371 temporal scales (Srivastava \& Vellend, 2005; Cardinale et al., 2012). In order to use ecosystem

372 services for biodiversity and ecosystem conservation, many ongoing discussions between

373 stakeholders are seeking a common ground in their respective objectives and agendas (Seddon et

374 al., 2016; Dee et al., 2017a). For example, Holt et al. (2011) quantified the types of services most

375 valued by the local community and stakeholders in a coastal wetland and established the

376 legislative mismatches that exist for protecting those ecosystem processes and functional that are 377 necessary to support the valued benefits. This represents an important step towards integration of 378 ecosystem services in frameworks like HEAs. While we acknowledge the complexity of these

379 discussions and the ongoing research on the topic (e.g. Paterson et al., 2011; Langhans et al., 380 2019), we emphasize that the integration of ecosystem services by stakeholders and within HEAs 381 will provide a great tool for the Strategic Plan for Biodiversity. To this end, approaches

382 considering ecosystems through network theory may be a great tool to consider the complexity

383 of ecosystems with the plurality of human influences and services (Dee et al., 2017b).

384 Considering ecosystem services in HEAs will benefit the safeguarding of ecosystems and the 385 maximization of benefits as stated in Goal D. The literature review detected an absence of HEA 386 studies specifically including Targets of this Goal, which highlights the need to better link HEAs 387 and ecosystem services.

388

389

\section{4. Conclusion}

391 HEAs have the potential to enhance marine conservation and management initiatives

392 significantly beyond 2020. The use of HEAs has been increasing steadily over the past decade 393 and is likely related to the establishment of the Strategic Plan for Biodiversity. To date, only a

394 few studies refer to specific Aichi Biodiversity Targets in their research objectives. If included, 395 HEAs could improve ecological research related to these Targets in a variety of ways: from the 396 development of ecological indices and increased understanding of species-ecosystem interaction, to the provision of tools for the prediction of multiple drivers of change and helping the establishment of frameworks for citizen science. All these actions could simultaneously increase 
399 understanding of ecosystem complexity in management schemes and decision-making in order to 400 achieve biodiversity goals.

401 We proposed five research priorities that could increase the effectiveness of HEAs in attaining 402 the Aichi Biodiversity Targets, with respect to their current state of completion. Holistic 403 approaches must appropriately assess the ecological functioning of marine ecosystems and their 404 environmental, social and sustainable economic development. There is a need to standardize the 405 vocabulary used for environmental assessments. Data collection needs to integrate system 406 complexity and data management needs to follow recognized international standards. Marine 407 biodiversity monitoring must consider single and multiple ecosystem components, must observe 408 variability at different scales and should link biodiversity conservation to ecosystem services to 409 support their sustainable uses.

410 Considering these priorities will help raise the value of HEAs to managers, ensuring greater 411 accuracy and predictive power in environmental management, and could greatly help preparation 412 of the work beyond the Strategic Plan for Biodiversity.

413

414

\section{Acknowledgements}

416 This work is the result of the 4th World Conference on Marine Biodiversity mentoring program. 417 We thank Stephanie Allen, Karen Mooney, Lidia Lins Pereira and Hashim Said, who were 418 involved in the initial discussions from which resulted in this work. We also wish to thank Peter 419 Duinker and Natalie Ban for their help during the literature review, along with two anonymous 420 reviewers for their helpful comments during earlier stages of this manuscript. Finally, we 421 particularly thank Philippe Archambault, Anna Metaxas and Paul Snelgrove for their implication 422 in the mentoring committee, who initiated this project, and their helpful comments and 423 suggestions during the writing process. 


\section{References}

427 Amengual J, Alvarez-Berastegui D. 2018. A critical evaluation of the Aichi Biodiversity Target

42811 and the Mediterranean MPA network, two years ahead of its deadline. Biological

429 Conservation 225:187-196. DOI: 10.1016/j.biocon.2018.06.032.

430 Arkema K, Abramson S, Dewsbury B. 2006. Marine ecosystem-based management: from

431 characterization to implementation. Frontiers in Ecology and the Environment 4:525-532. DOI:

432 10.1890/1540-9295(2006)4[525:MEMFCT]2.0.CO;2.

433 Atkins JP, Gregory AJ, Burdon D, Elliott M. 2011. Managing the Marine Environment: Is the

434 DPSIR Framework Holistic Enough? Systems Research and Behavioral Science 28:497-508.

435 DOI: $10.1002 /$ sres. 1111.

436 Authier MM, Commanducci FD, Genov T, Holcer D, Ridoux V, Salivas M, Santos MB, Spitz J.

437 2017. Cetacean conservation in the Mediterranean and Black Seas: Fostering transboundary

438 collaboration through the European Marine Strategy Framework Directive. Marine Policy

439 82:98-103. DOI: 10.1016/j.marpol.2017.05.012.

440 Baggio J, Hillis V. 2018. Managing ecological disturbances: Learning and the structure of social441 ecological networks. Environmental Modelling \& Software 109:32-40. DOI:

442 10.1016/j.envsoft.2018.08.002.

443 Ball IR, Possingham HP, Watts M. 2009. Marxan and relatives: software for spatial conservation

444 prioritisation. In: Moilanen A, Wilson KA, Possingham HP (eds), Spatial conservation

445 prioritisation: Quantitative methods and computational tools. Oxford University Press, United

446 Kingdom, 185-195.

447 Balmford A, Fisher B, Green RE, Naidoo R, Strassburg B, Turner KR, Rodrigues AS. 2011.

448 Bringing Ecosystem Services into the Real World: An Operational Framework for Assessing the

449 Economic Consequences of Losing Wild Nature. Environmental and Resource Economics

450 48:161-175. DOI: 10.1007/s10640-010-9413-2.

451 Baselga A. 2010. Partitioning the turnover and nestedness components of beta diversity. Global

452 Ecology and Biogeography 19:134-143. DOI: 10.1111/j.1466-8238.2009.00490.x.

453 Beaumont N, Austen M, Atkins J, Burdon D, Degraer S, Dentinho T, Derous S, Holm P, Horton

454 T, Ierland E, Marboe A, Starkey D, Townsend M, Zarzycki T. 2007. Identification, definition 
455 and quantification of goods and services provided by marine biodiversity: Implications for the 456 ecosystem approach. Marine Pollution Bulletin 54:253-265. DOI:

457 10.1016/j.marpolbul.2006.12.003.

458 Beever EA. 2006. Monitoring biological diversity: strategies, tools, limitations, and challenges. 459 Northwestern Naturalist 95:66. DOI: 10.1898/1051-1733(2006)87[66:mbdstl]2.0.co;2.

460 Bringezu S, Bleischwitz R. 2009. Sustainable resource management: global trends, visions and 461 policies. Routledge, London. 338 p.

462 Brown CJ, Saunders MI, Possingham HP, Richardson AJ. 2013. Managing for Interactions 463 between Local and Global Stressors of Ecosystems. PLoS ONE 8. DOI:

464 10.1371/journal.pone.0065765.

465 Brown EA, Chain FJ, Zhan A, MacIsaac HJ, Cristescu ME. 2016. Early detection of aquatic 466 invaders using metabarcoding reveals a high number of non-indigenous species in Canadian 467 ports. Diversity and Distributions 22:1045-1059. DOI: 10.1111/ddi.12465.

468 Bulleri F. 2009. Facilitation research in marine systems: state of the art, emerging patterns and 469 insights for future developments. Journal of Ecology 97:1121-1130. DOI: 10.1111/j.1365$470 \quad 2745.2009 .01567 . x$.

471 Burton CA, Huggard D, Bayne E, Schieck J, Sólymos P, Muhly T, Farr D, Boutin S. 2014. A 472 framework for adaptive monitoring of the cumulative effects of human footprint on biodiversity. 473 Environmental Monitoring and Assessment 186:3605-3617. DOI: 10.1007/s10661-014-3643-7.

474 Butchart S, Clarke M, Smith RJ, Sykes RE, Scharlemann J, Harfoot M, Buchanan GM, Angulo 475 A, Balmford A, Bertzky B, Brooks TM, Carpenter KE, Comeros-Raynal MT, Cornell J, Ficetola 476 FG, Fishpool L, Fuller RA, Geldmann J, Harwell H, Hilton-Taylor C, Hoffmann M, Joolia A, 477 Joppa L, Kingston N, May I, Milam A, Polidoro B, Ralph G, Richman N, Rondinini C, Segan 478 DB, Skolnik B, Spalding MD, Stuart SN, Symes A, Taylor J, Visconti P, Watson J, Wood L, 479 Burgess ND. 2015. Shortfalls and Solutions for Meeting National and Global Conservation Area 480 Targets. Conservation Letters 8:329-337. DOI: 10.1111/conl.12158.

481 Cardinale BJ, Duffy EJ, Gonzalez A, Hooper DU, Perrings C, Venail P, Narwani A, Mace GM, 482 Tilman D, Wardle DA, Kinzig AP, Daily GC, Loreau M, Grace JB, Larigauderie A, vastava DS, 
483 Naeem S. 2012. Biodiversity loss and its impact on humanity. Nature 486:59-67. DOI:

$48410.1038 /$ nature11148.

485 Carpenter SR, Mooney HA, Agard J, Capistrano D, Defries RS, Diaz S, Dietz T, Duraiappah 486 AK, Oteng-Yeboah A, Pereira HM, Perrings C, Reid W V., Sarukhan J, Scholes RJ, Whyte A. 487 2009. Science for managing ecosystem services: Beyond the Millennium Ecosystem Assessment. 488 Proceedings of the National Academy of Sciences of the United States of America 106:1305489 1312. DOI: 10.1073/pnas.0808772106.

490 Chan KMA, Ruckelshaus M. 2010. Characterizing changes in marine ecosystem services. F1000 491 Biology Reports 2:1-6. DOI: 10.3410/B2-54.

492 Cicin-Sain B, Belfiore S. 2005. Linking marine protected areas to integrated coastal and ocean 493 management: A review of theory and practice. Ocean \& Coastal Management 48:847-868. DOI: 494 10.1016/j.ocecoaman.2006.01.001.

495 Cisneros-Montemayor AM, Singh GG, Cheung WW. 2018. A fuzzy logic expert system for 496 evaluating policy progress towards sustainability goals. Ambio 47:595-607. DOI:

497 10.1007/s13280-017-0998-3.

498 Cook GS, Fletcher PJ, Kelble CR. 2014. Towards marine ecosystem based management in South 499 Florida: Investigating the connections among ecosystem pressures, states, and services in a 500 complex coastal system. Ecological Indicators 44:26-39. DOI: 10.1016/j.ecolind.2013.10.026.

501 Costello M, Basher Z, McLeod L, Asaas I, Claus S, Vandepitte L, Yasuhara M, Gislason H, 502 Edwards M, Appeltans W. 2017. Methods for the study of marine biodiversity. In: Walters M, 503 Scholes RJ (eds), The GEO Handbook on Biodiversity Observation Networks. Springer, Cham, $504129-163$.

505 Crain CM, Kroeker K, Halpern BS. 2008. Interactive and cumulative effects of multiple human 506 stressors in marine systems. Ecology Letters 11:1304-1315. DOI: 10.1111/j.1461507 0248.2008.01253.x.

508 Daigle R, Metaxas A, Balbar A, McGowan J, Treml EA, Possingham HP, Beger M. 2018. 509 Operationalizing ecological connectivity in spatial conservation planning with Marxan Connect. 510 Biorxiv. DOI: 10.1101/315424. 
511 Davidson LN, Dulvy NK. 2017. Global marine protected areas to prevent extinctions. Nature

512 Ecology \& Evolution 1:s41559-016-0040. DOI: 10.1038/s41559-016-0040.

513 Davies T, Maxwell S, Kaschner K, Garilao C, Ban N. 2017. Large marine protected areas

514 represent biodiversity now and under climate change. Scientific Reports 7:9569. DOI:

$515 \quad 10.1038 / \mathrm{s} 41598-017-08758-5$.

516 Dee LE, Allesina S, Bonn A, Eklöf A, Gaines SD, Hines J, Jacob U, nald-Madden E,

517 Possingham H, Schröter M, Thompson RM. 2017a. Operationalizing Network Theory for

518 Ecosystem Service Assessments. Trends in Ecology \& Evolution 32:118-130. DOI:

519 10.1016/j.tree.2016.10.011.

520 Dee LE, Lara M, Costello C, Gaines SD. 2017b. To what extent can ecosystem services motivate 521 protecting biodiversity? Ecology Letters 20:935-946. DOI: 10.1111/ele.12790.

522 van Denderen P, Bolam S, Hiddink J, Jennings S, Kenny A, Rijnsdorp A, van Kooten T. 2015. 523 Similar effects of bottom trawling and natural disturbance on composition and function of 524 benthic communities across habitats. Marine Ecology Progress Series 541:31-43. DOI: $52510.3354 /$ meps 11550 .

526 Diz D, Johnson D, Riddell M, Rees S, Battle J, Gjerde K, Hennige S, Roberts MJ. 2018.

527 Mainstreaming marine biodiversity into the SDGs: The role of other effective area-based 528 conservation measures (SDG 14.5). Marine Policy 93:251-261. DOI:

529 10.1016/j.marpol.2017.08.019.

530 Ehler C. 2017. A guide to evaluating marine spatial plans. UNESCO, Paris. 97 p.

531 Eriksen E, Gjøsæter H, Prozorkevich D, Shamray E, Dolgov A, Skern-Mauritzen M, Stiansen JE, 532 Kovalev Y, Sunnanå K. 2018. From single species surveys towards monitoring of the Barents 533 Sea ecosystem. Progress in Oceanography 166:4-14. DOI: 10.1016/j.pocean.2017.09.007.

534 Fisher B, Turner KR, Morling P. 2009. Defining and classifying ecosystem services for decision 535 making. Ecological Economics 68:643-653. DOI: 10.1016/j.ecolecon.2008.09.014.

536 Gari SR, Newton A, Icely J, Lowe CD. 2014. Testing the application of the Systems Approach

537 Framework (SAF) for the management of eutrophication in the Ria Formosa. Marine Policy 538 43:40-45. DOI: 10.1016/j.marpol.2013.03.017. 
539 Global Biodiversity Information Facility (GBIF). 2019. Global Biodiversity Information Facility.

540 Available at https://www.gbif.org (accessed 12/08/2019).

541 Global Ocean Observation System (GOOS). 2019. The Global Ocean Observation System.

542 Available at https://www.goosocean.org (accessed 12/08/2019).

543 de Groot RS, Wilson MA, Boumans R. 2002. A typology for the classification, description and

544 valuation of ecosystem functions, goods and services. Ecological Economics 41:393-408. DOI:

$545 \quad 10.1016 / \mathrm{S} 0921-8009(02) 00089-7$.

546 Gunn J, Noble BF. 2009. A conceptual basis and methodological framework for regional

547 strategic environmental assessment (R-SEA). Impact Assessment and Project Appraisal 27:258-

548 270. DOI: 10.3152/146155109X479440.

549 Gunn J, Noble BF. 2011. Conceptual and methodological challenges to integrating SEA and

550 cumulative effects assessment. Environmental Impact Assessment Review 31:154-160. DOI:

551 10.1016/j.eiar.2009.12.003.

552 Hagen M, Kissling WD, Rasmussen C, De Aguiar MA, Brown LE, Carstensen DW, Alves-Dos553 Santos I, Dupont YL, Edwards FK, Genini J, Guimarães PR, Jenkins GB, Jordano P, Kaiser-

554 Bunbury CN, Ledger ME, Maia KP, Marquitti FMD, Mclaughlin Ó, Morellato LPC, O'Gorman

555 EJ, Trøjelsgaard K, Tylianakis JM, Vidal MM, Woodward G, Olesen JM. 2012. Biodiversity,

556 Species Interactions and Ecological Networks in a Fragmented World. In: Woodward G, Jacob U 557 (eds), Advances in Ecological Research. Academic Press, 89-210.

558 Halpern BS, Walbridge S, Selkoe KA, Kappel CV, Micheli F, D’Agrosa C, Bruno JF, Casey KS, 559 Ebert C, Fox HE, Fujita R, Heinemann D, Lenihan HS, Madin EM, Perry MT, Selig ER, 560 Spalding M, Steneck R, Watson R. 2008. A Global Map of Human Impact on Marine 561 Ecosystems. Science 319:948-952. DOI: 10.1126/science.1149345.

562 Halpern BS, Frazier M, Potapenko J, Casey KS, Koenig K, Longo C, Lowndes J, Rockwood CR, 563 Selig ER, Selkoe KA, Walbridge S. 2015. Spatial and temporal changes in cumulative human 564 impacts on the world's ocean. Nature Communications 6:7615. DOI: 10.1038/ncomms8615.

565 Hampton SE, Strasser CA, Tewksbury JJ, Gram WK, Budden AE, Batcheller AL, Duke CS, 566 Porter JH. 2013. Big data and the future of ecology. Frontiers in Ecology and the Environment 567 11:156-162. DOI: 10.1890/120103. 
568 Harrop S. 2011. "Living In Harmony With Nature"? Outcomes of the 2010 Nagoya Conference 569 of the Convention on Biological Diversity. Journal of Environmental Law 23:117-128. DOI: $570 \quad 10.1093 / \mathrm{jel} / \mathrm{eqq} 032$.

571 Hilborn R. 2007. Managing fisheries is managing people: what has been learned? Fish and 572 Fisheries 8:285-296. DOI: 10.1111/j.1467-2979.2007.00263_2.x.

573 Holt A, Godbold J, White P, Slater A, Pereira E, Solan M. 2011. Mismatches between legislative 574 frameworks and benefits restrict the implementation of the Ecosystem Approach in coastal 575 environments. Marine Ecology Progress Series 434:213-228. DOI: 10.3354/meps09260.

576 Jantke K, Jones KR, Allan JR, Chauvenet A, Watson J, Possingham HP. 2018. Poor ecological 577 representation by an expensive reserve system: Evaluating 35 years of marine protected area 578 expansion. Conservation Letters 11:e12584. DOI: 10.1111/conl.12584.

579 Jarvis RM, Breen B, Krägeloh CU, Billington RD. 2015. Citizen science and the power of public 580 participation in marine spatial planning. Marine Policy 57:21-26. DOI:

581 10.1016/j.marpol.2015.03.011.

582 Johnson D, Lee J, Bamba A, Karibuhoye C. 2014. West African EBSAs: Building capacity for 583 future protection. Journal of Coastal Research 70:502-506. DOI: 10.2112/SI70-085a.1.

584 Jones FC. 2016. Cumulative effects assessment: theoretical underpinnings and big problems.

585 Environmental Reviews 24:187-204. DOI: 10.1139/er-2015-0073.

586 Judd A, Backhaus T, Goodsir F. 2015. An effective set of principles for practical implementation 587 of marine cumulative effects assessment. Environmental Science \& Policy 54:254-262. DOI: 588 10.1016/j.envsci.2015.07.008.

589 Kareiva P, Tallis H, Ricketts T, Daily G, Polasky S. 2011. Natural Capital: Theory and Practice 590 of Mapping Ecosystem Services: Theory and Practice of Mapping Ecosystem Services. Oxford: 591 Oxford University Press.

592 Kelble CR, Loomis DK, Lovelace S, Nuttle WK, Ortner PB, Fletcher P, Cook GS, Lorenz JJ, 593 Boyer JN. 2013. The EBM-DPSER Conceptual Model: Integrating Ecosystem Services into the 594 DPSIR Framework. PLoS ONE 8:e70766. DOI: 10.1371/journal.pone.0070766. 
595 Kraan C, Dormann CF, Greenfield BL, Thrush SF. 2015. Cross-Scale Variation in Biodiversity596 Environment Links Illustrated by Coastal Sandflat Communities. PLOS ONE 10:e0142411. DOI: 597 10.1371/journal.pone.0142411.

598 Lacoursière-Roussel A, Howland K, Normandeau E, Grey EK, Archambault P, Deiner K, Lodge 599 DM, Hernandez C, Leduc N, Bernatchez L. 2018. eDNA metabarcoding as a new surveillance 600 approach for coastal Arctic biodiversity. Ecology and Evolution 8:7763-7777. DOI:

601 10.1002/ece3.4213.

602 Lagabrielle E, Crochelet E, Andrello M, Schill SR, Arnaud-Haond S, Alloncle N, Ponge B. 603 2014. Connecting MPAs - eight challenges for science and management. Aquatic Conservation: 604 Marine and Freshwater Ecosystems 24:94-110. DOI: 10.1002/aqc.2500.

605 Langhans SD, Jähnig SC, Lago M, Schmid-Kloiber A, Hein T. 2019. The potential of 606 ecosystem-based management to integrate biodiversity conservation and ecosystem service 607 provision in aquatic ecosystems. Science of The Total Environment 672:1017-1020. DOI: 608 10.1016/j.scitotenv.2019.04.025.

609 Legendre P. 1993. Spatial Autocorrelation: Trouble or New Paradigm? Ecology 74:1659-1673. 610 DOI: $10.2307 / 1939924$.

611 Legendre P, Gauthier O. 2014. Statistical methods for temporal and space-time analysis of 612 community composition data. Proceedings. Biological sciences / The Royal Society 613 281:20132728. DOI: 10.1098/rspb.2013.2728.

614 Levin PS, Fogarty MJ, Murawski SA, Fluharty D. 2009. Integrated Ecosystem Assessments: 615 Developing the Scientific Basis for Ecosystem-Based Management of the Ocean. PLoS Biology 616 7:e1000014. DOI: 10.1371/journal.pbio.1000014.

617 Lewison RL, Rudd MA, Al-Hayek W, Baldwin C, Beger M, Lieske SN, Jones C, Satumanatpan 618 S, Junchompoo C, Hines E. 2016. How the DPSIR framework can be used for structuring 619 problems and facilitating empirical research in coastal systems. Environmental Science \& Policy 620 56:110-119. DOI: 10.1016/j.envsci.2015.11.001.

621 Link J. 2002. What does ecosystem-based fisheries management mean. Fisheries 27:18-21. 
622 Ma P, Ye G, Peng X, Liu J, Qi J, Jia S. 2017. Development of an index system for evaluation of 623 ecological carrying capacity of marine ecosystems. Ocean \& Coastal Management 144:23-30. 624 DOI: 10.1016/j.ocecoaman.2017.04.012.

625 Maggs JQ, Mann BQ, Cowley PD. 2013. Contribution of a large no-take zone to the 626 management of vulnerable reef fishes in the South-West Indian Ocean. Fisheries Research 627 144:38-47. DOI: 10.1016/j.fishres.2012.10.003.

628 Manley PN, Zielinski WJ, Schlesinger MD, Mori SR. 2004. Evaluation of a multiple-species 629 approach to monitoring species at the ecoregional scale. Ecological Applications 14:296-310. 630 DOI: $10.1890 / 02-5249$.

631 Margules C, Pressey R. 2000. Systematic conservation planning. Nature 405:243-253. DOI: $63210.1038 / 35012251$.

633 Millennial Environmental Assessment (MEA). 2005. Ecosystems and human well-being: 634 wetlands and water. Island Press, Washington. 137 p.

635 Nilsson M, Dalkmann H. 2001. Decision making and strategic environmental assessment. 636 Journal of Environmental Assessment and Policy Management 3:305-327. DOI: $63710.1142 / \mathrm{s} 1464333201000728$.

638 Norris K. 2012. Biodiversity in the context of ecosystem services: the applied need for systems 639 approaches. Philosophical Transactions of the Royal Society B: Biological Sciences 367:191640 199. DOI: $10.1098 /$ rstb.2011.0176.

641 Novaczek E, Howse V, Pretty C, Devillers R, Edinger E, Copeland A. 2017. Limited

642 Contribution of Small Marine Protected Areas to Regional Biodiversity: The Example of a Small 643 Canadian No-Take MPA. Frontiers in Marine Science 4:174. DOI: 10.3389/fmars.2017.00174.

644 Ocean Biogeographic Observation System (OBIS). 2019. Ocean Biogeographic Observation 645 System. Available at https://www.obis.org (accessed 12/08/2019).

646 OceanBestPractices (OBP). 2019. OceanBestPractices Repository. Available at 647 https://development.oceanbestpractices.net/page/about (accessed 12/08/2019). 
648 Palerm JR. 2000. An Empirical-Theoretical Analysis Framework for Public Participation in

649 Environmental Impact Assessment. Journal of Environmental Planning and Management 650 43:581-600. DOI: 10.1080/713676582.

651 Paterson D, Hanley N, Black K, Defew E, Solan M. 2011. Biodiversity, ecosystems and coastal 652 zone management: linking science and policy. Marine Ecology Progress Series 434:201-202. 653 DOI: $10.3354 / \mathrm{meps} 0279$.

654 Pesant S, Not F, Picheral M, Kandels-Lewis S, Bescot N, Gorsky G, Iudicone D, Karsenti E, 655 Speich S, Troublé R, Dimier C, Searson S, Acinas SG, Bork P, Boss E, Bowler C, Vargas C, 656 Follows M, Gorsky G, Grimsley N, Hingamp P, Iudicone D, Jaillon O, Kandels-Lewis S, Karp657 Boss L, Karsenti E, Krzic U, Not F, Ogata H, Pesant S, Raes J, Reynaud EG, Sardet C, Sieracki 658 M, Speich S, Stemmann L, Sullivan MB, Sunagawa S, Velayoudon D, Weissenbach J, Wincker 659 P. 2015. Open science resources for the discovery and analysis of Tara Oceans data. Scientific 660 Data 2:sdata201523. DOI: 10.1038/sdata.2015.23.

661 Pikitch E, Santora C, Babcock E, Bakun A, Bonfil R, Conover D, Dayton P, Doukakis P, 662 Fluharty D, Heneman B, Houde E, Link J, Livingston P, Mangel M, McAllister M, Pope J, 663 Sainsbury K. 2004. Ecosystem-Based Fishery Management. Science 305:346-347. DOI: 664 10.1126/science.1098222.

665 Pittman SJ. 2017. Seascape ecology. Wiley-Blackwell, Hoboken. 526 p.

666 van der Plas F. 2019. Biodiversity and ecosystem functioning in naturally assembled 667 communities. Biological Reviews 94:1220-1245. DOI: 10.1111/brv.12499.

668 Poisot T, Mounce R, Gravel D. 2013. Moving toward a sustainable ecological science: don't let 669 data go to waste! Ideas in Ecology and Evolution 6. DOI: 10.4033/iee.2013.6b.14.f.

670 Portman M. 2009. Involving the public in the impact assessment of offshore renewable energy 671 facilities. Marine Policy 33:332-338. DOI: 10.1016/j.marpol.2008.07.014.

672 Queiroz C, Meacham M, Richter K, Norström A V., Andersson E, Norberg J, Peterson G. 2015. 673 Mapping bundles of ecosystem services reveals distinct types of multifunctionality within a 674 Swedish landscape. Ambio 44:89-101. DOI: 10.1007/s13280-014-0601-0.

675 Rees SE, Foster NL, Langmead O, Pittman S, Johnson DE. 2018. Defining the qualitative 676 elements of Aichi Biodiversity Target 11 with regard to the marine and coastal environment in 
677 order to strengthen global efforts for marine biodiversity conservation outlined in the United

678 Nations Sustainable Development Goal 14. Marine Policy 93. DOI:

679 10.1016/j.marpol.2017.05.016.

680 Roche D, Kruuk L, Lanfear R, Binning SA. 2015. Public data archiving in ecology and

681 evolution: how well are we doing? PLoS Biology 13:e1002295 DOI:

682 10.1371/journal.pbio.1002295.

683 Roche D, Lanfear R, Binning S, Haff T, Schwanz L, Cain K, Kokko H, Jennions M, Kruuk L.

684 2014. Troubleshooting public data archiving: suggestions to increase participation. PLoS Biology

685 12:e1001779. DOI: 10.1371/journal.pbio.1001779.

686 Ryo M, Aguilar-Trigueros C, Pinek L, Muller L, Rillig M. 2019. Basic principles of temporal

687 dynamics. Trends in Ecology and Evolution 34:723-733. DOI: 10.1016/j.tree.2019.03.007.

688 Santos C, Ehler CN, Agardy T, Andrade F, Orbach MK, Crowder LB. 2019. Marine Spatial

689 Planning. In: Sheppard C (ed), World Seas: An Environmental Evaluation - Ecological Issues

690 and Environmental Impacts. Elsevier Science \& Technology, 571-592.

691 Sarker S, Rahman M, Yadav A, Islam M. 2019. Zoning of marine protected areas for

692 biodiversity conservation in Bangladesh through socio-spatial data. Ocean \& Coastal

693 Management 173:114-122. DOI: 10.1016/j.ocecoaman.2019.03.002.

694 Sustainable Development Goals (SDG). 2019. Sustainable Development Goals Knowledge

695 Platform. Available at https://sustainabledevelopment.un.org/(accessed 12/08/2019).

696 Secretariat of the Convention on Biological Diversity (CBD). 2010. Aichi Biodiversity Targets.

697 Available at https://www.cbd.int/sp/targets/ (accessed 12/08/2019).

698 Secretariat of the Convention on Biological Diversity (CBD). 2014. Global Biodiversity Outlook

699 4. Montréal. $155 \mathrm{p}$.

700 Seddon N, Mace GM, Naeem S, Tobias JA, Pigot AL, Cavanagh R, Mouillot D, Vause J,

701 Walpole M. 2016. Biodiversity in the Anthropocene: prospects and policy. Proceedings of the

702 Royal Society B: Biological Sciences 283:20162094. DOI: 10.1098/rspb.2016.2094. 
703 Srivastava DS, Vellend M. 2005. Biodiversity-ecosystem function research: Is It Relevant to

704 Conservation? Annual Review of Ecology, Evolution, and Systematics 36:267-294. DOI:

705 10.1146/annurev.ecolsys.36.102003.152636.

706 Stankey G, Clark R, Bormann B. 2005. Adaptive management of natural resources: theory,

707 concepts, and management institutions. United States Department of Agriculture. 77 p.

708 Tanhua T, Pouliquen S, Hausman J, O’Brien K, Bricher P, de Bruin T, Buck JJ, Burger EF,

709 Carval T, Casey KS, Diggs S, Giorgetti A, Glaves H, Harscoat V, Kinkade D, Muelbert JH,

710 Novellino A, Pfeil B, Pulsifer PL, de Putte A, Robinson E, Schaap D, Smirnov A, Smith N,

711 Snowden D, Spears T, Stall S, Tacoma M, Thijsse P, Tronstad S, Vandenberghe T, Wengren M,

712 Wyborn L, Zhao Z. 2019. Ocean FAIR Data Services. Frontiers in Marine Science 6:440. DOI:

$71310.3389 /$ fmars.2019.00440.

714 Tenopir C, Allard S, Douglass K, Aydinoglu A, Wu L, Read E, Manoff M, Frame M. 2011. Data

715 Sharing by Scientists: Practices and Perceptions. PLoS ONE 6:e21101. DOI:

716 10.1371/journal.pone.0021101.

717 Thomsen P, Willerslev E. 2015. Environmental DNA - An emerging tool in conservation for

718 monitoring past and present biodiversity. Biological Conservation 183:4-18. DOI:

719 10.1016/j.biocon.2014.11.019.

720 Tittensor DP, Walpole M, Hill SL, Boyce DG, Britten GL, Burgess ND, Butchart SH, Leadley

721 PW, Regan EC, Alkemade R, Baumung R, Bellard C, Bouwman L, Bowles-Newark NJ, Chenery

722 AM, Cheung WW, Christensen V, Cooper DH, Crowther AR, Dixon MJ, Galli A, Gaveau V,

723 Gregory RD, Gutierrez NL, Hirsch TL, Höft R, Januchowski-Hartley SR, Karmann M, Krug CB,

724 Leverington FJ, Loh J, Lojenga R, Malsch K, Marques A, Morgan DH, Mumby PJ, Newbold T,

725 Noonan-Mooney K, Pagad SN, Parks BC, Pereira HM, Robertson T, Rondinini C, Santini L,

726 Scharlemann JP, Schindler S, Sumaila RU, Teh L, van Kolck J, Visconti P, Ye Y. 2014. A mid-

727 term analysis of progress toward international biodiversity targets. Science 346:241-244. DOI:

$728 \quad 10.1126 /$ science. 1257484.

729 United Nations. 1992. Convention on Biological Diversity. 28 p.

730 de la Vega C, Horn S, Baird D, Hines D, Borrett S, Jensen L, Schwemmer P, Asmus R, Siebert

731 U, Asmus H. 2018a. Seasonal dynamics and functioning of the Sylt-Romo Bight, northern 
732 Wadden Sea. Estuarine, Coastal and Shelf Science 203:100-118. DOI:

733 10.1016/j.ecss.2018.01.021.

734 de la Vega C, Schuckel U, Horn S, Kroncke I, Asmus R, Asmus H. 2018b. How to include

735 ecological network analysis results in management? A case study of three tidal basins of the

736 Wadden Sea, south-eastern North Sea. Ocean \& Coastal Management 163:401-416. DOI:

737 10.1016/j.ocecoaman.2018.07.019.

738 Watson JR, Fuller EC, Castruccio FS, Samhouri JF. 2018. Fishermen Follow Fine-Scale Physical

739 Ocean Features for Finance. Frontiers in Marine Science 5:46. DOI: 10.3389/fmars.2018.00046.

740 White P, Godbold J, Solan M, Wiegand J, Holt A. 2010. Ecosystem services and policy: a review

741 of coastal wetland ecosystem services and an efficiency-based framework for implementing the

742 ecosystem approach. In: Harrison RM, Hester RE (eds), Ecosystem Services: Issues in

743 Environmental Science and Technology. Royal Society of Chemistry, 29-51.

744 Wilkinson MD, Dumontier M, Aalbersberg Ij, Appleton G, Axton M, Baak A, Blomberg N,

745 Boiten J-W, da Santos L, Bourne PE, Bouwman J, Brookes AJ, Clark T, Crosas M, Dillo I,

746 Dumon O, Edmunds S, Evelo CT, Finkers R, Gonzalez-Beltran A, Gray A, Groth P, Goble C,

747 Grethe JS, Heringa J, Hoen P, Hooft R, Kuhn T, Kok R, Kok J, Lusher SJ, Martone ME, Mons

748 A, Packer AL, Persson B, Rocca-Serra P, Roos M, van Schaik R, Sansone S-A, Schultes E,

749 Sengstag T, Slater T, Strawn G, Swertz MA, Thompson M, van der Lei J, van Mulligen E,

750 Velterop J, Waagmeester A, Wittenburg P, Wolstencroft K, Zhao J, Mons B. 2016. The FAIR

751 Guiding Principles for scientific data management and stewardship. Scientific Data

752 3:sdata201618. DOI: 10.1038/sdata.2016.18.

753 Yamakita T, Yamamoto H, Nakaoka M, Yamano H, Fujikura K, Hidaka K, Hirota Y, Ichikawa

754 T, Kakehi S, Kameda T, Kitajima S, Kogure K, Komatsu T, Kumagai NH, Miyamoto H,

755 Miyashita K, Morimoto H, Nakajima R, Nishida S, Nishiuchi K, Sakamoto S, Sano M, Sudo K,

756 Sugisaki H, Tadokoro K, Tanaka K, Jintsu-Uchifune Y, Watanabe K, Watanabe H, Yara Y,

757 Yotsukura N, Shirayama Y. 2015. Identification of important marine areas around the Japanese

758 Archipelago: Establishment of a protocol for evaluating a broad area using ecologically and

759 biologically significant areas selection criteria. Marine Policy 51:136-147. DOI:

760 10.1016/j.marpol.2014.07.009. 
761 Yeager LA, Cith M, McPherson JM, Williams ID, Baum JK. 2017. Scale dependence of 762 environmental controls on the functional diversity of coral reef fish communities. Global 763 Ecology and Biogeography 26:1177-1189. DOI: 10.1111/geb.12628. 


\section{Figure 1}

Number of articles per year adopting a Holistic Environmental Approach (HEA) identified in ISI Web of Knowledge.

(A) Number of HEA studies conducted in terrestrial, freshwater and marine environments

(light grey), including studies focusing only on marine environments (dark grey). (B)

Prevalence of each HEA within studies targeting marine environments only. Searches queried the title, abstract and keywords of peer-reviewed articles. Publication of the Aichi Biodiversity Targets in 2010 is represented by the black dashed vertical line.

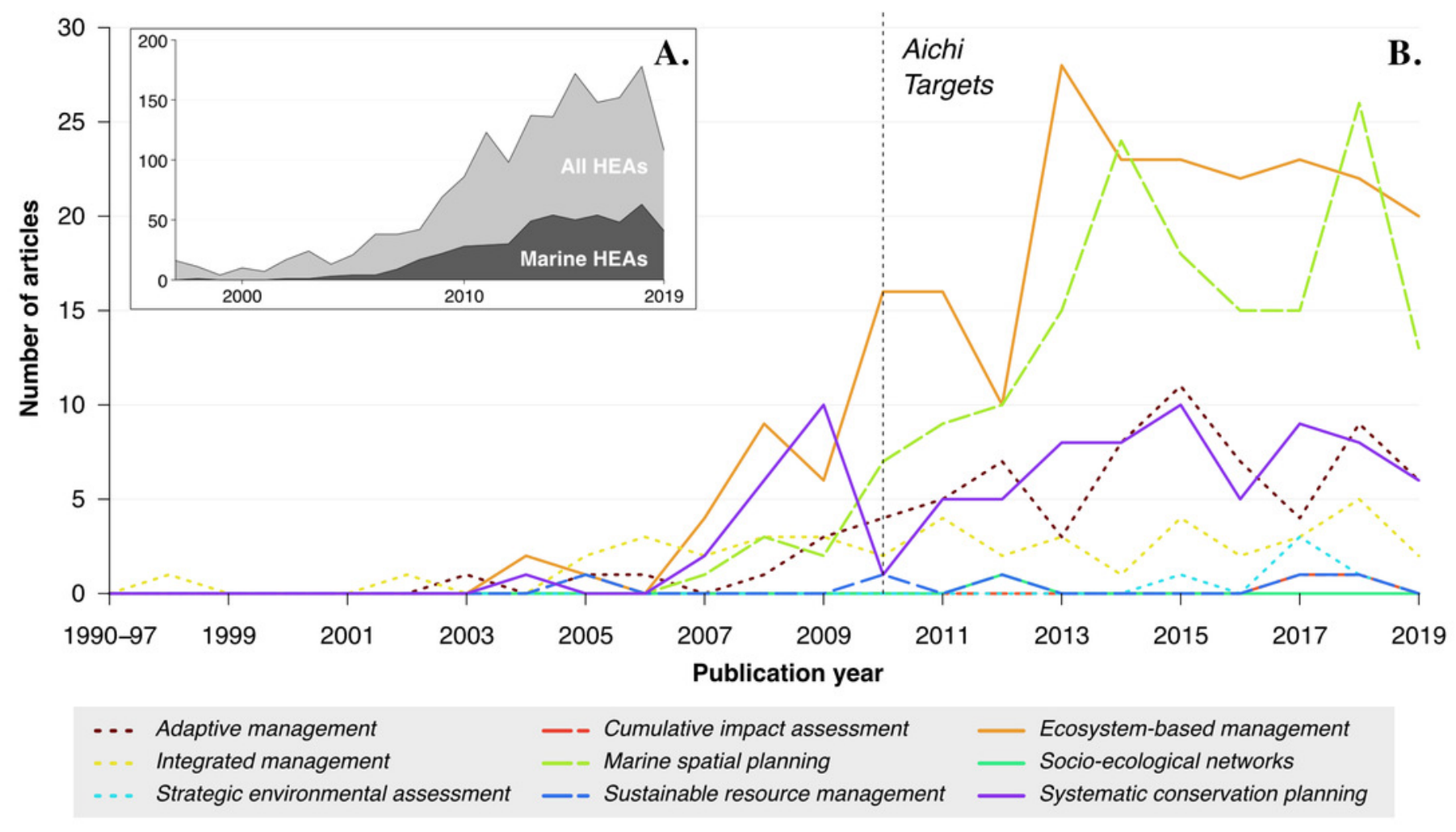




\section{Figure 2}

Conceptual diagram of interactions and relationships between the Strategic Goals (A), the Aichi Biodiversity Targets (B), Holistic Environmental Approaches (C), and the identified research priorities (D).

Targets have been summarized from Secretariat of the CBD (2010), and the letter before their number corresponds to the Goal to which they belong. Solid arrows represent direct relationships between sections, and dashed arrows represent secondary feedback.

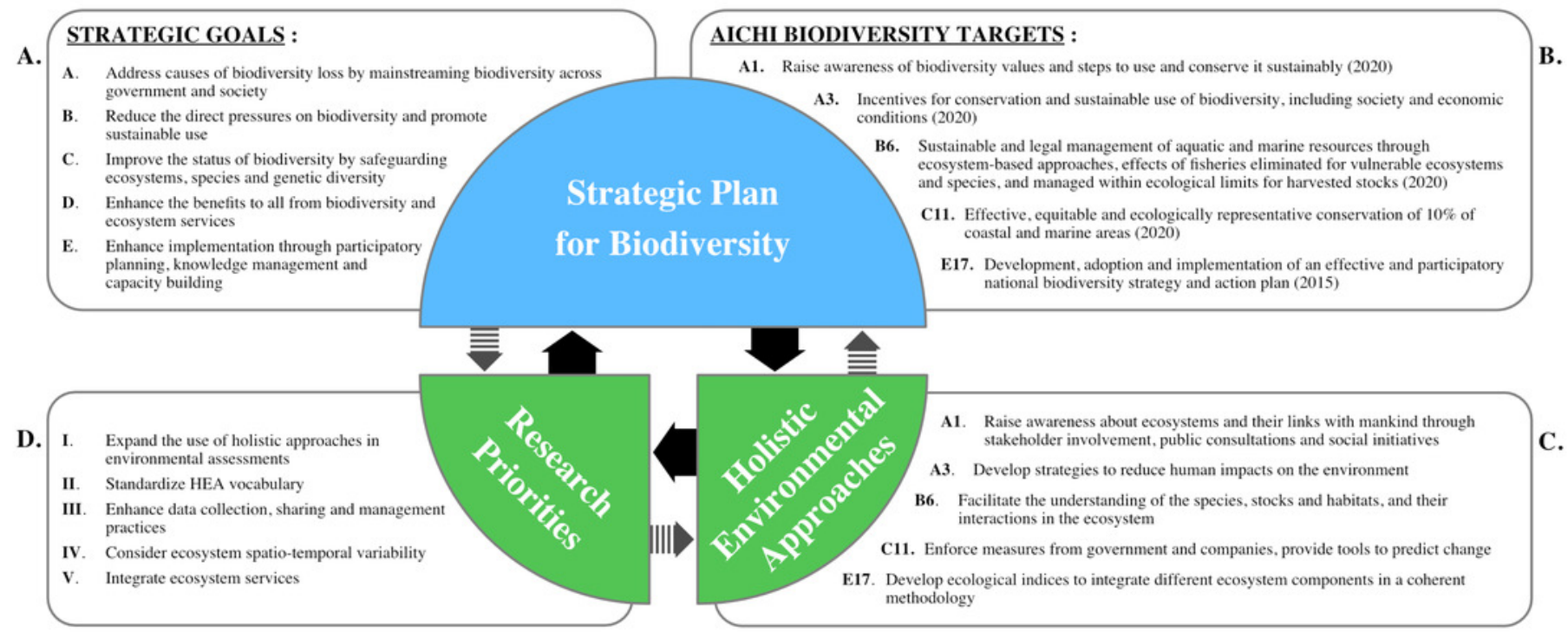




\section{Table $\mathbf{1}$ (on next page)}

Search terms used in ISI Web of Knowledge to characterize the relevance of Holistic Environmental Approaches (HEAs) to achieving the Strategic Plan for Biodiversity.

The different queries were limited from January 1990 to July 2019. Queries and search terms have been formatted with a regular expression syntax (REGEX) structured with conditional statements in italics, except for queries $2 . x$ which have searched only for one type of HEA at a time. 


\begin{tabular}{llr}
\hline ID & Query & Articles \\
\hline 1 & Criteria $A N D \underline{\text { HEAs }}$ & 1,648 \\
2 & Criteria $A N D \underline{\text { HEAs }} A N D$ “marine" & 505 \\
2.1 & Adaptive management & 69 \\
2.2 & Cumulative impact assessment & 2 \\
2.3 & Ecosystem-based management & 223 \\
2.4 & Integrated management & 43 \\
2.5 & Marine spatial planning & 159 \\
2.6 & Social-ecological network & 1 \\
2.7 & Strategic environmental assessment & 5 \\
2.8 & Sustainable resource management & 5 \\
2.9 & Systematic conservation planning & 83 \\
3 & Criteria $A N D$ HEAs $A N D$ “marine" $A N D$ “Aichi” & 12 \\
\hline
\end{tabular}

1 Criteria: (ecolog* $O R$ ecosystem $O R$ environment* $O R$ habitat $O R$ species) $A N D$ "biodiversity" 2 HEAs: "adaptive management" $O R$ ("cumulative effect* assessment" $O R$ "cumulative impact* 3 assessment") $O R$ "ecosystem.based management" $O R$ ("integrated management" $O R$ "integrative 4 management") $O R$ "marine spatial planning" $O R$ "social.ecological network" $O R$ "strategic

5 environmental assessment" $O R$ "sustainable resource management" $O R$ "systematic conservation 6 planning" 


\section{Table 2 (on next page)}

Links between articles adopting a Holistic Environmental Approach (HEA) obtained for Query 3 of the literature review and the Aichi Biodiversity Targets. 


\begin{tabular}{lllrr}
\hline ID & Article & Type of HEA considered & $\begin{array}{r}\text { Targets } \\
\text { considered }\end{array}$ & $\begin{array}{r}\text { Targets } \\
\text { as objectives? }\end{array}$ \\
\hline 1 & $\begin{array}{l}\text { Amengual \& Alvarez- } \\
\text { Berastegui (2018) }\end{array}$ & Marine spatial planning & 11 & Yes \\
2 & $\begin{array}{l}\text { Cisneros-Montemayor, } \\
\text { Singh \& Cheung (2018) }\end{array}$ & Adaptive management & $1,3,6,17$ & Yes \\
3 & Davidson \& Dulvy (2017) & Systematic conservation planning & 11,12 & No \\
4 & Davies et al. (2017) & Systematic conservation planning & $6,10,11,12$ & No \\
5 & Diz et al. $($ 2018) & Marine spatial planning & 11 & Yes \\
6 & Jantke et al. $(2018)$ & Systematic conservation planning & 11 & Yes \\
7 & Johnson et al. $(2014)$ & Ecosystem-based management & 6,11 & Yes \\
8 & Lagabrielle et al. (2014) & Marine spatial planning & 11,19 & No \\
9 & Novaczek et al. $(2017)$ & Adaptive management & 11 & No \\
10 & Rees et al. (2018) & Marine spatial planning & 11 & Yes \\
11 & Sarker et al. $(2019)$ & Integrated management & 11 & Yes \\
12 & Yamakita et al. $(2015)$ & Strategic environmental assessment & 11 & No \\
\hline
\end{tabular}

1 